\title{
The New National Security Strategy of Poland: Ready to Face the Challenges of the Twenty-First Century
}

\section{Bogdan Klich *}

It gives me distinct pleasure to welcome the first meeting of the Euro-Atlantic Security Study Group held in Poland. Krakow, which was the seat of Polish kings in medieval times, may be considered a fitting venue for such an event. This city used to be a hub of Poland's activities on a regional and international scale, and as in the past, today it continues to serve as Poland's foremost place of scholarship and intellectual debate. Meeting here, amongst a gathering of distinguished guests from more than a dozen countries in Europe and North America, I recall this tradition of multilateral relations and learning, convinced that the proceedings of the Euro-Atlantic Security Study Group will also help to stimulate a lively debate on issues of import to the international community.

The Institute of Strategic Studies, on behalf of which I welcome all of you here, would not have missed an opportunity to involve itself in cooperation with the PfP Consortium of Defense Academies and Security Studies Institutes. Poland has traversed a long road, from being a NATO partner state, then a PfP member, finally moving towards full membership in the Alliance in 1999. As deputy defense minister, I pushed strongly for the extension of friendship and cooperation to countries that did not yet belong to NATO. This effort has not been in vain. In retrospect, some remarkable changes have taken place in the neighborhood of the Euro-Atlantic Community. A lot of countries of Central and Eastern Europe have been brought into the fold of the North Atlantic Alliance and in a matter of months will enter the European Union. Through conferences, publications, and research programs organized under the auspices of the Institute of Strategic Studies, we have sought to map and analyze the transformation that has been ongoing in the geostrategic arena. The meeting of the Euro-Atlantic Security Study Group is further evidence of the strong engagement of the Institute in these activities, which, let me emphasize, have an intentionally strong orientation towards the policy dimension.

The topic of the Krakow meeting of the Euro-Atlantic Security Study Group is crisis management in the context of contemporary and future security challenges. The relevance of this topic speaks for itself when we reflect upon the Allied operations in Afghanistan and Iraq, as well as the continuing peacekeeping missions in the Western Balkans. Poland has taken part in these missions led by the awareness that security is indivisible and, hence, we must all face up to any challenges that distort peace and instigate conflict. However, like other countries in the world, we have had to adjust to the new breed of challenges and threats to security, which were demonstrated in full

* Dr. Bogdan Klich is President of the ISS Foundation, Institute for Strategic Studies, Krakow, Poland. 
force on September 11, 2001. The two main factors that must be taken into account today include:

- The changing topography of the international system. The world today is littered with so-called "failed states," or "states of concern," as well as new actors such as transnational criminal networks. These failed states include those areas of the world where meaningful governance has for all intents and purposes broken down, providing opportunities for an influx of criminal groups and producing all manner of destabilizing agents. There are also countries where the fabric of governance may be strong but pronouncedly undemocratic, and which harbor hostile intentions toward the rest of the international community. The argument of last resort of these dictatorial regimes often tends to be the threat to use weapons of mass destruction (WMD). Finally, there are new actors on the international stage which defy traditional categorization and which do not conform to the conception of a geographically identifiable entity. These include transnational criminal networks, including terrorist groups, such as Al-Qaeda. The "head office" of these organizations cannot be traced to any fixed address, and their logistical lines of supply and training tend to be scattered across the globe, while the sting of their activities may be felt at any place in the world and at any point in time.

- New conceptions of conflict and warfare. The reconceptualization of traditional notions of conflict and crisis may be felt nowhere more deeply than in Poland. For decades Poland labored under the Communist system, stuck in a system of seemingly immutable parameters of two military blocs, the Warsaw Pact and NATO, each subscribing to a clear view of an adversary and each armed to the teeth with hard armor fitted onto relatively static and bloated military forces. However, in the dying days of the Cold War world, we have seen new conflicts coming to the fore, such as those which engulfed the former Yugoslavia and threatened to set the former U.S.S.R. on fire. These conflicts-driven by ethnonationalism, economic deprivation, and other conflict-generating domestic conditions - fixed the attention of the UN and fueled the transformation of NATO and other international organizations dedicated to international cooperation and security management. In short, we have had to drop the traditional perception of military conflict as a declared war between State X and State Y, and instead refocus and retool our capabilities towards managing conflict that most often at least have their genesis within a country's frontiers, quite often involving war crimes and flagrant abuses of human rights.

If these tectonic shifts, which lie at the root of the new security environment in the age of globalization and affect our threat perception, were difficult to discern, the onslaught of "hyper-terrorism" on the United States shed light on the grave threats and challenges to security that will confront the world for years, if not decades, to come. The nexus of failed states, international terrorism, and the proliferation of WMD has emerged as the most serious challenge to international security. The specter of terrorists sneaking into a country, setting up sleeper cells, and procuring non- 
conventional weapons in order to strike at strategic Western targets when the order is given from some place halfway around the world has redefined our fundamental notions of what constitutes modern-day warfare and what the responses to these threats should be. Clearly, the potential of asymmetric attacks has rendered established practices in the field of external and internal security in need of a major overhaul, to say nothing of highlighting the artificiality of such an internal/external security construct.

Poland has taken note of the complexity of these new security challenges and threats, and has moved to address them in an appropriate manner. A cornerstone of the nation's new approach to conflict management, as well as its overall strategic thinking in security policy, is the recently unveiled "National Security Strategy of the Republic of Poland." I cannot help but remark on the timing of this meeting of the Euro-Atlantic Security Study Group, which comes on the heels of the signing of the Strategy by the Polish President on 8 September 2003.

Since work on this document was accompanied by a great deal of internal policy debate (also within the Parliamentary Committee on Foreign Affairs, of which I happen to be Deputy Chairman), I would like to take this opportunity to shed some light on the main arguments resonating in these discussions as well as the key outlines of the new Strategy. To date, the development of an independent Polish security policy had been guided by two previous national security strategies, the first adopted in 1992 and the second in 2000. The "Assumptions of Polish Security Policy" produced at the beginning of the previous decade set the strategic objectives of Poland that all governments since then have consistently followed. These concern the tying of Polish security policy to the security guarantees offered by NATO and by membership in the European Union, involving active participation in the EU's still-evolving framework of security and defense policy. Once membership in the Atlantic Alliance had been attained, it became necessary to develop new frames of reference, new ways of defining security policy in an Alliance context. This is reflected in the security strategy for Poland unveiled in 2000. Owing to the lack of presidential signature, it remained essentially a government guidance document, and not a state-level policy concept.

The events of September 11 and the lessons learned subsequently from the operations in Afghanistan and Iraq have provided new ways of looking at international security, in particular regarding the capabilities that each state must tailor in order to meet to prospective security exigencies. Poland has not remained idle in this period of policy reassessment. While the strategic calculus remains the same-the strengthening of Poland's position in and enhancing its contribution to NATO and the EU- the changing means of security policy and of Poland's geostrategic context prompted the Polish Government in 2002 to summon an interdepartmental team of experts under the coordination of the Ministry of Foreign Affairs, which was assigned the task of producing a new national security strategy reflecting contemporary and future security challenges as well as approaches to crisis management, influenced by the upcoming membership of Poland in the EU and the current and coming wave of NATO enlargement. 
The National Security Strategy of Poland remains essentially congruent with the EU security concept "A Secure Europe in a Better World," unveiled by Javier Solana at the Thessaloniki Council Summit in June of 2003, which, moreover, accords in principle with the strategic reassessment made by our American allies a year before. Poland has recognized that the main challenges in the future no longer derive from any instability on its doorstep, since our neighborhood is now quite safe, but rather from challenges intertwined with pathological manifestations of some of the negative ramifications of globalization. Many of these were mentioned at the start of my essay. They include the differential level and pace of development of states, leaving fragile states exposed to socio-political decay and criminality; the vulnerability of international telecommunication networks to asymmetric attacks; and the threat of WMD proliferation.

Because many of these highlighted factors are external in origin, although they engender internal consequences, the role of the internal security apparatus (including special services, the police, border guard, civil defense units, etc.) has been highlighted in the new strategy. The potential of terrorist attacks, using biological agents, for example, puts the importance of the veterinary services in a new light. The gravity of critical infrastructure protection, further linked to economic security concerns, is another issue that deserved serious consideration. The importance of the non-military dimension of security policy — especially civilian crisis management capacity - is properly acknowledged on the pages of the new National Security Strategy.

Having said this, the external source of security threats - often quite distant, as the Al-Qaeda-Taliban connection in Afghanistan illustrated-necessitates an acceleration of armed forces reform. We have agreed that Poland needs ever more professional, mobile, well-equipped rapid reaction forces able to undertake a full spectrum of military missions, more often than not taking place far away from Poland's borders. Polish troops should be geared towards a proactive defense posture, not merely a reactive one.

The deployment of 2,500 Polish troops in Iraq and, concomitantly, the assumption of command of a Multinational Division (MND) helping to bring stability to that country, attest to Poland's determination to pursue crisis management and post-conflict rehabilitation wherever sources of insecurity and instability may lie, and whenever these may be judged significant enough to merit risking the lives of Polish servicemen.

The National Security Strategy continues Poland's long-standing policy of pursuing security in common with its allies. The armed forces are intended to fulfill obligations arising due to the membership of Poland in NATO, as well as contribute to the operationalization of the European Security and Defense Policy (ESDP). Consistent with the EU security concept, we have recognized the paramount importance of NATO in guaranteeing Europe's security. It is not meant to belittle the importance of the EU's security and defense dimension, but is simply a statement of the reality of current ability and readiness of NATO's allied forces to respond to security threats and challenges anytime and anywhere, both within the perimeter of the Euro-Atlantic community and on the global stage. However, in my view what will prove very handy 
for the purpose of crisis management is the EU's holistic approach to the issue. The development of specialized capabilities (rule of law, police, etc.) by the European Union is a needed step towards addressing all stages of conflict management, including prevention, intervention, and post-conflict rehabilitation.

The National Security Strategy asserts the position of Poland as being in favor of the UN's continued responsibility, as enshrined in the UN Charter, for the maintenance of international peace and security. However, as we have pointed out in various international arenas, the UN (and for that matter other organizations, such as the OSCE) needs to be revitalized. A way forward has been signaled by Poland in the proposed "New Political Act for the United Nations for the 21st Century."

I should conclude this overview of Poland's new security strategy by pointing out that it is designed to serve as both the basis and point of departure for individual sectoral strategies to be prepared by relevant ministries tasked with the implementation of security policy. Another significant attribute of this document, and indeed a novelty in the Polish experience of policy planning, is that it stipulates that the substance and implementation of the strategy will be subject to a periodic review process.

Speaking from the point of view of a parliamentarian, I hope that no political force in this country would question the need for assured, stable provisions for the defense sector and national security in general. The record of the Seym in supporting armed forces modernization programs gives a good deal of encouragement in this regard. In this context, I might also add that over the course of the past two years my colleagues and I in the Polish Parliament have worked assiduously to guarantee a legislative basis for a system of crisis management at home-for instance, passing laws regulating the response of state organs to natural disasters and other emergencies.

I am aware that these brief remarks on Poland's national security strategy, and in particular the vision articulated therein of responding to crisis situations, will set the stage for an interesting discussion among the experts gathered here. The Institute of Strategic Studies wishes to involve itself in the future endeavors of the Euro-Atlantic Security Study Group, and, more broadly, the PfP Consortium of Defense Academies and Strategic Studies Institutes. In particular, we are eager to share the experiences of Poland in adjusting its politico-security structures to meet the security needs of today and tomorrow with our PfP partners. I hope that today's meeting is but a first step towards this end. 